NINA KELEBERDA

Associate Professor, PhD in Philosophy,

Chair of Humanitarian Disciplines; Russian Customs Academy, Rostov Branch, Rostov-on-Don, Russia.

EKATERINA TISHCHENKO

Associate Professor, PhD in Law, Deputy Dean of the Law Faculty, SFedU, Rostov-on-Don, Russia.

\title{
DEVIANCE, CULTURE AND EUROPEAN VALUES
}

The Globalization shifts in a cultural landscape of the $\mathrm{EU}$ as a factor of introduction in the European area of big people mass with other cultural and religious values create problems of cross-cultural communications actual particularly the conduct we now call "hate crime" [1,2]. The line of contact of extremely opposite values in the European context inspires hot spot for negative deviations. One of barriers for these phenomena is legal practice. In this regard, the offered course coincides with the direction of the European researches and is focused on development of unique crosscultural competence of Masters of Law.

Today the culture of modern multicultural Europe is facing an intense challenges as basic values of the European Union have to come into relations with values of other cultures. The line of their contact has a potential opportunity for different deviance. Crime, criminal law and criminal justice are no longer purely national issues in today's Europe [3,4].

Criminal conduct is becoming increasingly denationalized because of the offenders' easily cross borders and the emergence of the Internet and cyberspace. It is also increasingly common for individuals either to face criminal proceedings or to become victims of crime outside their own countries [5]. These factors are driving the need for a better understanding of crime. They include questions such as how best to respond to crimes that affect more than one state; how to establish an appropriate balance between respect for national traditions of criminal justice and the tendency to harmonize legislation with practice; and how to make sure that it is possible for suspects, offenders and victims to rely upon an adequate level of protection of their fundamental rights wherever they come into contact with a criminal justice system in Europe. Criminal policy is therefore increasingly prominent on the political agenda of the key European players, above all the European Union and the Council of Europe. Attention to the European experience stems from a number of reasons. The difficulties that arise in EU now cannot stop the fact that the Europeanization of fundamental rights based on the judgments of the Supreme Court, on agreements, on the Nice Summit of 2000, the constitutional traditions common has increased awareness of the fact that genuine guarantees should not hiccup in the powers of the politic, but in the depths of peoples' culture. European culture - is the fundamental basis of European integration. Being Open Society it is facing number of challenges about which K. Popper wrote in his book [6]. In this sense, Russian practice is fundamentally different. The aim of the project is to introduce into Russian Legal Education the Europe's approaches to 
the convergence of cultural and criminal processes in contemporary social life $[7,8]$. The world community has the important task to ensure the fight against extremism and terrorism. The projected development of social and political processes requires knowledge of legislative experience and judicial practice of foreign countries. In European countries special bodies or organizations are set up to coordinate crime prevention activities. They collect information, evaluate programs, plan for crime prevention, as well as coordinate the activities of the police and other specialized bodies. It is necessary to learn this experience and use it for Russian education. Creation and implementation of the course is aimed at disseminating knowledge and information to attract scientific interest.

Crime and deviance constitute aclassic pathology within societies which has led to a variety of responses on the political and social levels in Europe and all over the world [8]. Measures to prevent and fight against crime tend to be based on different factors, but it is clear that not only law but a cultural resource can lead to effective strategies of crime prevention (especially hate crimes). These and other considerations led the authors to suggest the idea for the Law Faculties students to focus on the study of the legal definitions of social creativity, the situation of different faiths and guarantees freedom of conscience and expression and practice of social control for crime in this area (especially 'hate crimes') [7].

Today Russian universities especially law departments have not similar crossdisciplinary courses yet. Students of law departments are in great need in change of the habitual point of view and expansion of professional horizons.

As we offer a unique content and cross-disciplinary approach in the course "Deviance, Culture and European Values", it will be particularly useful for researchers in this field. So there will be several beneficiaries of the project as the following:

1. Master degree students will get not only deeper knowledge of the nature of modern challenges for EU integration processes, but also the following skills: to offer a concept model, to invent and test methods and tools, to improve and develop their intellectual and cultural level, to build a path for professional development, to create and edit legal texts in the Russian (state) language, covering issues of professional and scientific activities. The course is focused on forming analytical competencies: Master graduate researchers will be capable to develop and implement the current scientific and research-topractice project.

2. The Russian academic community will get new content about the European integration process.

3. This course aims at building up the professors' specialization. The Russian teaching community will get an example of using the European experience of Open Education Resources for Russian higher education (publication of lectures, learning materials).

4. Civil society representatives will get knowledge about legal ways to settle complicated relations between freedoms of rights to faith, speech and creativity that are increasingly common in the secular context of Europe and Russia (presentation of students' works and on websites).

Besides, the project will get more attention due to the annual All-Russian conference; its program includes photos and reviews that will be posted on the websites of the Master program. Some materials, such as notebooks and booklets, will be distributed during the event. The most successful student projects within 'Deviance, Culture and European Values' will be presented at the conference.

Finally, to prolong the effect of the project all content and academic publications will build a foundation so that 
a distance education course can be created as a separate module and used for other universities of Southern Russia due to distance-learning technologies.

The development of Education methods and approaches is based on the traditions of Russian legal educational institutions. However, the content and structure reflect changes and development trends of Russian criminal law and practice, taking into account the functioning of European legal thought and mechanisms and new needs in the preparation of the legal profession. The development of didactic materials has a common goal - they serve as methodical support for Master's competence in criminal law: knowledge and skills needed to pass the test on the course 'Deviance, Culture and European Values'.

As we offer a unique cross-disciplinary approach in the course 'Deviance, Culture and European Values', it will be particularly useful for researchers in this field. So the academic community will be provided with new content and original approaches concerning European integration process. Master degree students who will have attended this course will get deeper knowledge about the nature of modern challenges for EU integration processes and about legal ways to resolve them. Civil society representatives will get knowledge about legal ways to settle complicated relations between freedoms of rights to faith, speech and creativity that are increasingly common in the secular context of Europe and Russia.

Thus, target group of our project is PhD students, post-doctoral students and young researchers under the age of 35 who are not directly in contact with European integration studies. Didactic materials help students handle the information needed to solve specific practical problems, deepen their legal knowledge by studying the European practice, improve their cultural level to get a competitive advantage in the professional labor market. Some of the recommendations may be useful for the Russian practice - in particular for the development of new legal situations and awareness of new threats, basing on EU's criminal law.

Three sections will be allocated for didactic materials in order to reach the goals and objectives of the project. The first section contains general guidance of the course program. The second one formulates guidelines for seminar preparation, as well as a wide range of tasks for each topic. Literature required, individual assignments, incidents, quizzes, tests, questions for discussions specified in this section, in relation to each topic. The third section provides guidance on the organization and conduct of project control tasks, which can be implemented both individually and in groups, depending on the complexity.

Master degree students will get necessary skills and deeper knowledge of the nature of modern challenges for EU's integration processes. Didactic materials suggest the presence of a wide range of guide for further reading annotations, web links and a list of regulations on the subject. The Russian teaching community will get a new content of discipline with original approaches and an example of using European experience of Open Education Resources for Russian higher education. Didactic materials will be distributed through the funds of the web-libraries, with free access. They will be posted on the websites of the Master program.

The purpose for creating of the course has an educational and methodological component. It will master the course of lectures in a more comfortable manner. According to our experience, professional success comes to the lawyers who know how to develop the right and convincing position on various issues. Criminal cases on hatred are of great complexity. This course will explain what a hate crime and 
a hate incident are and how frequent hate crimes are in the EU. You will learn who the victims and perpetrators are, what effect hate crimes have on a person, and what the current challenges are. This course will introduce you to the law and culture around hate crime and inform you how to respond to such incidents according to the European experience.

Popular Culture has long been absent from the syllabus, eschewed by researchers and viewed condescendingly sometimes even by its most adept practitioners. It has come a long way to become the thriving academic discipline it is today. Just as the term Popular Culture describes the widest range of practices, Popular Culture Studies cover the most heterogeneous objects. While this very diversity makes it exciting as a research field, it presents a challenge in terms of methods and approaches. So, in contemporary society, criminal practices and cultural dynamics intertwine within the experience of everyday life. Many common forms of criminality emerge out of criminal and deviant subcultures that are themselves shaped by shared conventions of meaning, symbolism, and style. These subcultures in turn produce intensely collective experiences and emotions that define their member's identities and reinforce their members' marginal social status.

The methodology used for the offered cross-disciplinary course is based on modules. The course consists of three modules, developed by three relevant skilled teachers. Each of the modules is integrating three subjects (Religious Studies, Cultural Studies, Criminal Law) in the structure of one discipline subordinated to the common educational aim and stage-by-stage tasks of its achievement. Comparative, contrastive and descriptive methods are used for the content of each module. The working methodology includes interdisciplinary, interactive and innovative teaching methods characterized by dividing each working group of students into micro-groups of 3-5 people according to students' personal wishes. Pedagogical technologies combine case studies, group discussions, group projects, roundtables, role playings ("The European Court Model") and scenario analysis. In-class discussions will be based on visual materials and, analyses of practical cases, with emphasis made on both theoretical and professional practical aspects.

The duration of the course is 36 classes, or 72 hours. When each module is completed, the students will be asked if they are satisfied with the quality of the lectures and seminars. There will be one midterm test and the final project presented in workshop. Quizzes will be given throughout the semester to assess how weekly materials are learnt. In addition, there are homework assignments that include problems to be solved and submitted each week.

The stage of the course implementation represents a dynamic iterative process. The course is repeated every year as the implementation of the Master program and is designed for a capacity upgrade listener's audience. Thus, 25 students (minimum number of people in the group) will be trained on the offered course, which means minimum 75 people during three years of the project. Audience: Master degree students graduated from humanitarian departments of SFedU, Law Faculty in particular, and all those interested in EUrelated studies.

The authors analyze religious factors in national cultures aiming at finding ways for peaceful cultural and social integration amid instability and tenseness of social, economic and cultural contacts in EU and Russia

Thus, the content of the first module of the course 'The European Values: a Historically Philosophical Review' presents an overview of the basic philosophical theories about freedoms of conscience, creativity and speech in European philosophical studies. Then we take a look at the geographic distribution of traditional 
religions in the EU, including processes of secularization, and make Models of relations between the state and religious associations in secular multi-confessional context of some European countries. The problems of interaction between art and press and traditional religious views in secular society as challenges or cooperation will be covered at the end of the course. The most attention will be paid to the coordination of freedoms on the basis of tolerance.

The second module named 'Conceptualizing and Measuring Culture and Crime' is to suggest the idea to the Law Faculty students to focus on studying the legal definitions of social creativity, the situation of different faiths and guarantees freedom of conscience and expression and practice of social control of crime in this area (especially hate crimes).

The last module named 'Policy-Making to Fight and Prevent Hate Crime in the EU' is to discuss hate crime as a specific type of violent conduct and criminal activity, and social control efforts designed to curb such violence. It is assumed that the soon-to-be legal experts will acquire unique expertise and skills in the process of studying this course. For example, these are the abilities: to offer a concept model, to invent and test methods and tools, the ability to improve and develop their intellectual and cultural level, to build a path for professional development, to create and edit legal texts in the Russian (state) language, covering issues of professional and scientific activities. The module is focused on forming analytical competencies: Master graduate researchers must be capable of developing and implementing the current scientific and scientifically-practical project. So in this project the different forms that hate crimes can take and the impact of these crimes upon victims and their communities are examined. Students will learn about the scope of current hate crime laws within Europe and Russia and consider the effectiveness of police and other criminal justice responses. We will also consider the reasons why perpetrators commit hate offences and debates surrounding the use of both enhanced prison sentences and alternative modes of intervention. Throughout the module, we will draw from the latest developments in research and politics to ensure that you have full understanding of various issues relating to hate crime and its causes.

Bringing to the conclusion it is necessary to emphasise one thing: modern multicultural problems among which there is "hate crime" appears in the line of intercultural contacts - a potential opportunity for different deviances which can be possible to forecast and correct on the strong base of fundamental rights. This essay is focused on interdisciplinary approach of whether philosophical and religious studies contribute to multicultural knowledge of lawyers.

\section{REFERENCES}

1. Crime and deviance in the EU Key findings from EU funded social sciences and humanities research projects, Luxembourg: Publications Office of the European Union, 2011

2. Deflem, Mathieu. Popular Culture, Crime and Social Control. 1st ed. Bingley: Emerald Group Publishing Limited. 2010.

3. Giddens A. Fate, Risk and Security. In: A. Giddens. Modernity and Self-Identity: Self and Society in the Late Modern Age. Cambridge: Polity Press, 1991

4. Ferelly J., Hayward. K., Young, J. Cultural Criminology: An invitation. London: Stage. 2008.

5. Goode E. Deviant Behaviour: Patterns, Source and Control. - NY-L: Plenum Press.1990

6. Popper, Karl. The Open Society and Its Enemies (Volumes I and II). Princeton University Press, 2013

7. Richard McMahon. Crime, Law and Popular Culture in Europe, 1500-1900, Routledge, 2013

8. Gilinsky J. Modern Deviance: Methodology, Theory and Practice. London: UK Academy of Education, 2016. 


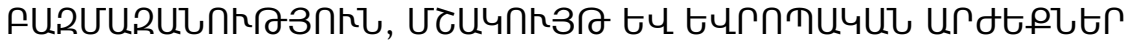 UHUU PGLGFGPNU}

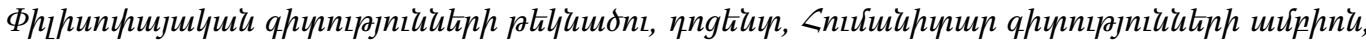

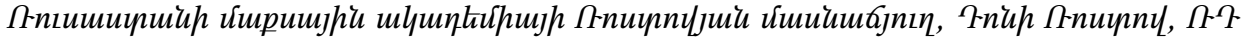

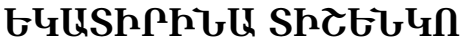

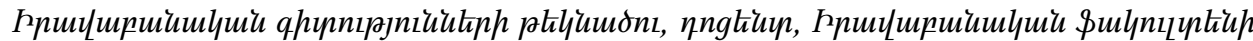

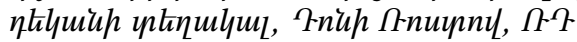

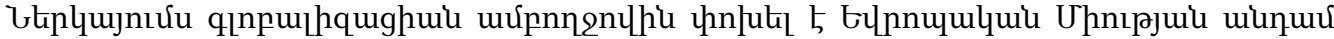

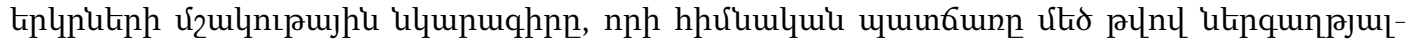

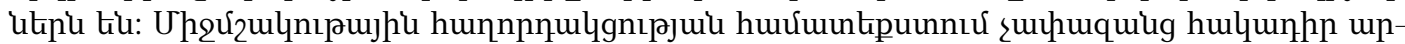

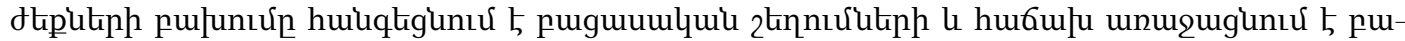

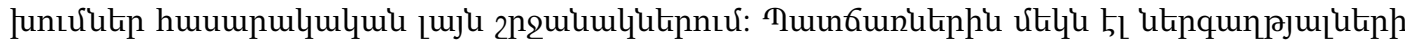

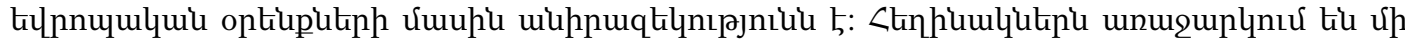

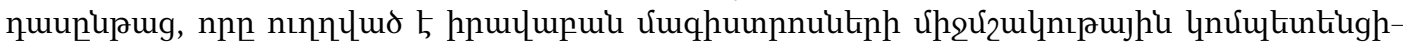
ujh quipqugưuin:

\section{РАЗНООБРАЗИЕ, КУЛЬТУРА И ЕВРОПЕЙСКИЕ ЦЕННОСТИ НИНА КЕЛЕБЕРДА \\ Кандидат философских наук, дочент кафедры гуманитарных дисииплин Российской таможенной академии. Ростовский филиал. Ростов-на-Дону, Россия}

\section{ЕКАТЕРИНА ТИХЧЕНКО}

Кандидат юридических наук, доцент. Заместитель декана юридического факультета. Ростов-на-Дону, Россия

В настоящее время глобализационные процессы коренным образом изменили культурологическую характеристику стран-участников ЕС, основной причиной чего является большое количество беженцев. В контексте межкультурной коммуникации конфликт ценностей приводит к отрицательным отклонениям и зачастую становится причиной конфликтов в широких слоях общественности. Другой причиной является незнание беженцами европейских законов. Авторы предлагают курс, направленный на развитие у магистрантов-юристов навыков межкультурной компетенции. 